\title{
NON CUSTODIAL TREATMENT OF OFFENDERS: THE MALAYSIAN APPROACH*
}

\author{
Mohammad Akram**
}

\begin{abstract}
Crime as a social phenomenon has existed throughout the history of mankind, however it is increasingly realized that to reduce the crime rate and deleterious effects of crime on society, a constructive and meaningful policy is required. There is a growing awareness that one such constructive approach is the change from custodial measures of punishment to non-custodial measures. This policy is in line with crime control programs. In all societies efforts are being made to control crime as well as to relieve offenders, their families and societies as a whole from the ill-effects of crime by adopting community-oriented programs of punishment. This article examines closely the aims, the effectiveness and the use of various noncustodial measures. The measures to be discussed in this paper include absolute and conditional
\end{abstract}

A revised version of a paper presented at the $3^{\text {rd }}$ ASLI Conference in Shanghai on 25 $5^{\text {th }}$ and $26^{\text {th }}$ May 2006.

Associate Professor, Department of Public Law, Ahmad Ibrahim Kulliyyah of Laws, International Islamic University Malaysia, Kuala Lumpur. 
discharge, binding over, probation, fine, community services and attendance centers.

\section{INTRODUCTION}

Crime as a social phenomenon has existed in all countries of the world and the focus in all the penal systems have been to reduce the crime in society. It has also been increasingly realized that to reduce crime and its deleterious effects on the society, a constructive and meaningful penal policy is needed. To achieve this objective there is a growing emphasis to replace custodial measures of punishment to noncustodial measures. This policy is in line with the crime control programmes adopted in all the countries of the world.

It remains a fact that a large number of offenders are dealt with by custodial measures of punishment globally. It is estimated that 8.7 million people are held in penal institutions throughout the world either as a pretrial detainees (remand prisoners) or having been convicted and sentenced. Half of those are in the United States, Russia and China. All these countries have ratio of atleast 460 prisoners per 100,000 of the national population. ${ }^{1}$ In Malaysia the prison population in the year 2004 was $42,284^{2}$ and the ratio of atleast 200 prisoners per 100,000 of the total national population. A majority of the prisoners in Malaysian prisons are short termers who are serving sentences for commission of petty offences, ${ }^{3}$ who could otherwise be dealt with by non-custodial measures. In this paper it is proposed to make an appraisal of non-custodial measures of treatment of offenders as applied in Malaysia and to suggest some measures for the improvement in the light of experience of some other countries. The non-custodial measures to be discussed include absolute or conditional discharge and binding over, probation, fine and attendance centres.

\footnotetext{
$1 \quad$ Walmsley Roy, World Prison Population List (third edition) British Home Office. Research Findings 166/2002.

2 See New Straits Times, August 16, 2004, p. 4.

3 Mohammad Akram, "Short Term Imprisonment in Malaysia: An Overview,” [2001] MLJ Ixiii.
} 


\section{NEED FOR NON-CUSTODIAL MEASURES}

Imprisonment is the main and extensively used form of punishment in Malaysia. The object of imprisonment is to meet the contemporary demands of deterrence, retribution and rehabilitation. The question arises whether imprisonment can achieve these objectives of the criminal justice system. The fact is that in Malaysia prisons consist of a substantial number of prisoners who are undergoing short term sentences. ${ }^{4}$ The ill effects of short term imprisonment on the first offenders who are not dangerous and are not guilty of serious offences are well known. They are subjected to the worst impact of imprisonment and forced to live in the company of professional and hardcore criminals. The objectives of punishment are not achieved when an offender is sent to prison for short period. Such short stay does not in any way help in the rehabilitative programme rather it brings social stigma and thereby hampers in their readjustment to the community. ${ }^{5}$

The current figures show that the total prisoners population in Malaysian prison is 42,284 - 10,000 more than its capacity. This number indicates that the prisons in Malaysia are overcrowded and unable to cope the growing number of offenders.

Besides this, the cost of maintaining prisons is very high. In the year 2003, the Government of Malaysia spent RM 245 millions on the maintenance of Prisons Department. The cost of maintaining one person in prison per day is RM 35, and of which RM 3.80 is for food, while the rest goes towards the warder's pay, utility and medical bills, and cost for activities and workshops to keep the prisoners occupied. ${ }^{6}$

\footnotetext{
$4 \quad$ In the year 2004 in the Malaysian prisons there were 31632 prisoners or $48 \%$ of the total prison population serving less than six months imprisonment. See Annual Report Malaysian Prison Department 2004 p. 104.

$5 \quad$ Supra note 3.

$6 \quad$ See Supra note 2.
} 
Penal Population (All types of Institutions) - Annual Admission From 1990-2004

\begin{tabular}{|l|l|l|l|l|l|l|l|l|}
\hline Years & Prisons & $\begin{array}{l}\text { Henry } \\
\text { Gurney } \\
\text { School }\end{array}$ & $\begin{array}{l}\text { Rehabili- Centres } \\
\text { tation } \\
\text { Centres } \\
\text { Protective } \\
\text { Custody }\end{array}$ & $\begin{array}{l}\text { Drug } \\
\text { Rehabili- } \\
\text { tation } \\
\text { Centres }\end{array}$ & Total & $\begin{array}{l}\text { Increase/ } \\
\text { Decrease } \\
\text { Over } \\
\text { Previous } \\
\text { Years }\end{array}$ & $\begin{array}{l}\text { Rate of } \\
\text { Increase } \\
\text { Decrease }\end{array}$ \\
\hline 1990 & 50373 & 294 & 210 & 118 & 184 & 51179 & 1580 & 3.19 \\
\hline 1991 & 63241 & 256 & 725 & 56 & 130 & 64408 & 13231 & 25.85 \\
\hline 1992 & 49531 & 273 & 651 & 41 & 0 & 50496 & -13914 & -21.3 \\
\hline 1993 & 58522 & 406 & 602 & 2 & 0 & 59532 & 9036 & 17.89 \\
\hline 1994 & 57041 & 412 & 643 & 2 & 0 & 58098 & -1434 & -2.41 \\
\hline 1995 & 52737 & 426 & 779 & 104 & 0 & 54046 & -4052 & -6.97 \\
\hline 1996 & 54682 & 395 & 872 & 119 & 0 & 56068 & 2022 & 3.74 \\
\hline 1997 & 59073 & 425 & 1158 & 73 & 0 & 60729 & 4661 & 8.31 \\
\hline 1998 & 71844 & 428 & 1342 & 141 & 0 & 73755 & 13026 & 20.45 \\
\hline 1999 & 78983 & 473 & 876 & 1 & 0 & 80333 & 6578 & 8.9 \\
\hline 2000 & 78134 & 87 & 946 & 30 & 0 & 79197 & -1136 & -1.4 \\
\hline 2001 & 84096 & 132 & 1139 & 61 & 0 & 85428 & 6321 & 1.98 \\
\hline 2002 & 92314 & 282 & 1239 & 41 & 0 & 93876 & 8448 & 9.89 \\
\hline 2003 & 121302 & 171 & 1089 & 34 & 0 & 122596 & 28720 & 30.59 \\
\hline 2004 & 124514 & 155 & 1050 & 34 & 0 & 125753 & 3157 & 2.58 \\
\hline
\end{tabular}

Source: Annual Report 2004, Prison Department of Malaysia

The above table reveals that penal population in Malaysia has been on rise. The annual admission from 1990-1994 disclose that there has been an alarming jump from 51179 to 125753 offenders in all the penal institutions. The presence of such a large number of prisoners in Malaysian prisons makes it impossible for the prison management to apply the United Nations Standard Minimum Rules (Treatment of Offenders) 1954 and the Prison Rules. This increase is an indicator to use non-custodial measures in the cases of those offenders who have not committed serious offences so as to reduce pressure on penal institutions and to provide the opportunity to the respective institutions to use more vigorously and effectively the reformative and rehabilitative methods of treatment of offenders. 


\section{ABSOLUTE OR CONDITIONAL DISCHARGE AND BINDING OVER}

An absolute discharge is employed by the court where it regards the process of arrest, charge and hearing in itself sufficient punishment. The court requires nothing from the offender and imposes no restriction on future conduct. However, the order follows a finding of guilt but the court does not proceed to record a conviction. This discharge differs from conditional discharge in which, the courts allow the offender to return to the community without subjecting to any supervision. The usual way in which sentencing options are exercised require the offender to enter into a recognizance which imposes certain conditions. Discharge is conditional upon entering into recognizane. Failure to comply with conditions laid down can lead to further action.

Where the court finds the offender guilty but does not record a conviction, it may discharge the offender absolutely or impose conditions for a specified period. Sections 173A, and 294 of the Malaysian Criminal Procedure Code (hereafter referred C.P.C.) confer powers on the courts to release the offenders on absolute or conditional discharge and binding over.

Section 173A of the C.P.C. provides following conditions to be fulfilled before the court can grant absolute discharge.

1) It applies to all offenders.

2) The court does not record the conviction.

3) The court gives consideration to age, character, antecedents, health and mental condition of the offender, the triviality of the offence and extenuating circumstances of the commission of the offence.

4) It is inappropriate to inflict any punishment other than nominal punishment.

5) The period of bond does not exceed more than three years.

6) The charge of complaint is dismissed after admonition or caution to the offender.

The essential requirements for the application of Section 294 of the C.P.C. are as follows: 
1) It applies to adult offenders only.

2) The conviction is recorded.

3) The court gives consideration to age, character, antecedents, health and mental conditions of the offender, triviality of the offence, and extenuating circumstances of the offence.

4) It is used where the offence is punishable with imprisonment.

5) It is expedient to release the offender on probation of good conduct.

The cases in which absolute discharge are granted are such in which the law has confessedly failed because the accused is morally blameless and no deterrent purpose would be served by his punishment and also the cases in which the court believes that the accused's conduct was an isolated instance and no further pressures are required to keep him up to the scratch. ${ }^{7}$

The condition which forms part of the discharge is that the offender should commit no further offence during the specified period which may be up to three years. If further offence is committed during the specified period the court may sentence the offender not only for that offence but also for original offence which gave rise to the conditional discharge. The essence of the conditional discharge is therefore a threat or warning. The court is prepared to impose no sanction for the present offence on condition there is no new offence within the specified period. ${ }^{8}$

In Public Prosecutor v. Onn, ${ }^{9}$ the accused was tried by a Magistrate under Section 380 of the Penal Code for stealing in a dwelling house two and a quarter yards of cloth. At the close of the trial, the trial Magistrate found the charge proved and proceeded to exercise his powers under Section 173A of the C.P.C. and discharged the offender conditionally on his entering into a bond for good behaviour and imposed the conditions of the bond under Section 294A of the C.P.C. ${ }^{10}$

Ruper Cross, The English Sentencing System, London, Butterworth, (1971), p. 134.

Andrew Ashworth, Sentencing and Criminal Justice, London, Butterworth (1995), p. 255.

[1969]1 MLJ 4.

Section 294A of the Criminal Procedure reads as under:

"When any person is required by any Court to execute a bond with or without sureties and in such bond the person executing it binds himself to keep peace or binds himself to be of good behaviour the Court may 
In revision of the petition, the deputy public prosecutor drew the attention of the learned judge that the conditions of the bond under Section 294A requiring the offender to be placed under supervision of a probation officer for a defined period and prohibiting him from associating with other persons were illegally imposed.

The learned judge agreed with the deputy public prosecutor and held that a condition requiring the offender to be of good behaviour in paragraph (b) of Section 173A has no punitive effect in as much as it merely enjoins the offender to behave like any other law abiding citizen. But the same cannot be said of the nature of the two conditions set out in Section 294A of the C.P.C. Section 294 A contains conditions which are punitive in effect and which, if imposed, would amount to some form of punishment being inflicted on the offender. Accordingly to inflict any of these conditions on an offender, who has not been convicted would be repugnant to the accepted notion of the justice.

In this case, the learned judge gave a clear guideline to the courts that when exercising power under Section 173A of the C.P.C., the court should not proceed to conviction. To impose any condition on the release of the offender would be against the accepted principles of natural justice.

Public Prosecutor v. Idris,${ }^{11}$ further sheds some light on the application of Sections $173 \mathrm{~A}$ and 294 of the C.P.C. of the C.P.C. In this case the accused was charged before the Magistrate with negligent driving in contravention of the Motor Vehicles proclamation. He pleaded guilty. The learned Magistrate took the view that the offence was not a serious one and bound the accused over for six months under Section 294 of the C.P.C. Against this order the public prosecutor appealed.

require that there be included in such bond on or more of the following conditions namely:

(a) a condition that such person shall remain under the supervision of some other person named in the bond during such period as may be herein specified;

(b) such conditions for securing such supervision as the Court may think it desirable to impose;

(c) such conditions with respect to residence, employment, associations, abstentions from intoxicating liquors or with respect to any matter whatsoever as the Court may think it desirable to impose." 
On appeal the learned judge of the High Court set aside order of the binding over ad held that Section 294 of the C.P.C. only applies in the case of an offence punishable with imprisonment as the offence in this case was punishable with a fine only, the order of binding over under Section 294 was wrongly made and must be set aside.

As to the application of Section 173A and Section 294, the learned judge observed that there is a certain amount of overlapping between the two sections in the sense that very often a case may be appropriately dealt with under either of them. There are, however certain differences, which must be carefully observed. Section $173 \mathrm{~A}$ is applicable in all cases, triable in the Magistrate Courts irrespective of the nature of the prescribed punishment and it is to be observed that where it is proposed to exercise powers given by it the court should not proceed to conviction. Section 294 on the other hand, which only applies in a case of adult offenders, can only be used of, where a person has been convicted and where his conviction is for an offence punishable with imprisonment without the option of a fine.

\section{PROBATION}

Criminal justice plays an important role in correction and rehabilitation of offenders. Probation system is the agency through which criminal justice can render invaluable contribution in the treatment, correction and rehabilitation of the offenders. Probation as a non-custodial measure has proved successful especially with first offenders and as a cost effective mechanism for screening out of offenders who do not require confinement in place of detention. It is one of the outstanding measure which is designed to work for early reformation and resocialisation of criminals while they remain in the community as other citizens by subjecting them to certain conditions which they must comply with and by providing them with guidance, supervision and aid.

In Malaysia the system of probation is provided in the Criminal Procedure Code and the Child Act 2001. The law makes a difference between youthful offender and the first offender in respect of probation. The sentencing court is conferred with the power to grant probation to the youthful offender under the Child Act and under Sections 293 and 294 of the Criminal Procedure Code. The Court is empowered to release 
any person convicted of any punishable with imprisonment on probation of good conduct with such conditions as the Court may deem fit including a condition that such person will remain under the supervision of some other person named therein.

In case of youthful offenders, the Criminal Procedure Code allows the release of offenders on probation. When a youthful offender ${ }^{12}$ is convicted by a Court of any offence punishable by fine or imprisonment, such court may instead of passing any sentence on the offender, either discharge him after admonition, or deliver to his parent or guardian on executing a bond with or without sureties, or the Court may deal with him in the manner prescribed by the Child Act. ${ }^{13}$

The Child Act provides comprehensive provisions for the grant of probation in case of child. If a Court For Children by or before which a child is found guilty of an offence other than any grave crime, voluntarily causing grievous hurt, rape, incest or outraging modesty or unnatural sexual offences, is of opinion that having regard to the circumstances, including the nature of the offence and character of the child, it is appropriate to do so, the court may make a probation order. A probation order shall be for a period not less than one year and not more than three years from the date of the order as may be specified in the probation order. ${ }^{14}$ The probation order shall state the following conditions to be observed by the child for securing the good conduct and supervision or preventing a repetition by him same or other offences:

(a) The probationer shall be required to submit during probation period to the supervision of probation officer.

(b) It shall specify that probationer will not commit any crime during the probation order.

(c) The probation order shall also contain other requirement such as that the probationer shall reside in probation hostel, attend educational institutions recommended by the probation officer and shall remain indoors at his place of residence (probation hostel or home) during hour to be specified. ${ }^{15}$

Section 2 of the C.P.C. defines a youthful offender as one aged between 10 to below 16 .

13 Section 293 of the Criminal Procedure Code.

14 Section 98(1) \& (3) of the Child Act 2001.

15 Section 98 (4) of the Child Act 2001. 
The Child Act also makes provision for probation of a child who has not committed any offence but is uncontrolable. In such situation the Act provides that a probation order may be made by the Court For Children either on request by the parent or guardian of a child who is beyond control or in any case the court deems expedient to deal with the child. If the Court decides to place the child on probation it shall ask the probation officer to submit a report. ${ }^{16}$ The child will remain on probation for such period not exceeding three years under the supervision of the probation officer, ${ }^{17}$ or the child may be required to stay in probation hostel for a period not exceeding twelve months. ${ }^{18}$

In the cases of youthful offenders, ${ }^{19}$ the Criminal Procedure Code also allows the release of offenders on probation. When a youthful offender is convicted by a Court of any offence punishable by fine or imprisonment, such Court may instead of passing any sentence discharge him after admonition, or deliver to his parent or guardian on executing a bond with or without sureties, or the Court may deal with him in the manner prescribed by the Juvenile Courts Act. ${ }^{20}$

The provisions which deal with children or youthful offenders in the Children For Court and the C.P.C. appear to be adequate to make use of probation or to release such offenders on executing a bond as an alternative to conventional form of punishment. The Courts have invoked them in some cases.

In Johari bin Ramli, ${ }^{21}$ the accused aged 21 or 22 years, was convicted on a charge of possession of house-breaking instruments, an offence under Section 28(i)(ii) of the Minor Offences Ordinance 1955.

$16 \quad$ More than 300 probation officers are working under the Ministry of Social Welfare. For details see Mohammad Akram, "Probation of Offenders in Malaysia: A Plea,” [1996] 4 CLJ cxi. See Sections 46 and 47 of the Child Act 2001. Section 61 of the Child Act empowers the Minister to establish probation hostels. In Malaysia 11 probation hostels have been established. In addition to this, there are 8 probation schools established by the Department of Social Welfare where the children placed on probation can be sent. For details see Supra note 16. Section 2 of the Criminal Procedure Code defines a youthful offender as an aged between 10 to below 16 .

20 Section 293 of the Criminal Procedure Code.

$21 \quad$ [1956] 22 MLJ 56. 
He had a number of previous convitions but details of these were not recorded by the Magistrate who only noted that "The accused admits several (six) previous convictions for theft, house breaking and possession of stolen property.” The learned Magistrate sentenced the accused to 10 days imprisonment.

On revision the learned judge called for a probation officer's report and after considering the report, he set aside the sentence and substituted an order of binding over the accused in the sum of RM500 to be of good behaviour and to come for sentence when called upon and in the meantime to be under the supervision of a probation officer. With regard to selection of sentence Spencer Wilkinson J. said:

"I would like to take this opportunity of pointing out to the Magistrates the great importance of a careful selection of sentence of sentence in regard to young men of this type who having criminal record going back to an early stage can still be looked upon, although over aged, as juvenile delinquents. There are often circumstances in which short terms of imprisonment have to be imposed, but it should be borne in mind that a series of short terms of imprisonment has very little effect in reforming wringdoers and often has a tendency to convert them into habitual offenders." 22

The Courts have always shown concern towards young offenders, and have insisted that young offenders be kept out of prison. In Tukiran bin Taib v. Public Prosecutor, ${ }^{23}$ the accused was charged in the Magistrate's Court with the theft of 167 coconuts under Section 379 of the Penal Code. He pleaded guilty to the charge and was given four months imprisonment. As the accused was 17 or 18 years, the learned judge of the High Court called or the record of the proceeding to satisfy himself as to the propriety of the prison sentence imposed by the Magistrate Court. Setting aside the sentence of imprisonment and making an order of committal to Henry Gurney School, Bellamy J. observed:

$\begin{array}{ll}22 & \text { Id, at p. } 57 . \\ 23 & {[1955] 21 \text { MLJ } 24 .}\end{array}$


Before passing sentence the Magistrate should first make careful inquiries regarding the background, antecedents and character of the convicted person, and this is particularly of importance when the convicted person is a young offender and it is contemplated imposing a sentence of imprisonment. A probation officer's report should always be called for, and, a Magistrate should not hesitate to adjourn the case in order to obtain such a report before passing sentence. In experienced Magistrate's are in doubt as to the proper manner of bringing in such a report. The probation officer should be called as a witness and give the substance of this report.

In Public Prosecutor v. Tan King Hua, ${ }^{24}$ the accused aged 16 years was convicted by the Magistrate to one year imprisonment for theft. On revision of the case, the learned judge set aside the sentence of imprisonment and held it was wrong for the leaned Magistrate to impose a sentence of imprisonment in this case in view of the age of the accused. Highlighting the importance of non-institutional treatment of offenders, Lee Hun Hoe J. observed:

Youthful offenders should be treated with sympathy and understanding. In most cases they get into trouble because of poor family upbringing and lack of proper control. Advantage should be taken of those provisions of the Criminal Procedure Code which deal with youthful offenders. Every thing reasonable should be done to avoid sending such an offender to prison if another suitable punishment is available.

In Malaysia, no specific statute exists for the grant of probation to adult offenders. However, in Singapore the Probation of Offenders Act 1975 has been in use for granting probation to juvenile and adult offenders. The provisions of the Act can be applied to all offenders who have been of an offence (provided that the offence is not one of which sentence is fixed by law). The Court must be satisfied with the character of the offender and the nature of the case among other conditions before placing the offender on probation. ${ }^{25}$

\footnotetext{
$24 \quad$ [1966]1 MLJ 24.

25 Section 5 of the Probation of Offenders Act 1975.
} 
In Singapore about $75 \%$ of the probation population are below 18 years of age. Of these about $65 \%$ are in schools or technical schools. $15 \%$ come from single parents and $75 \%$ come from nuclear families. ${ }^{26}$

In Singapore to complement regular probation officers the probation service has 350 Voluntary Probation Officers, who befriend and guide probationers, help to steer people back to the straight and narrow path. It has been found that these Voluntary Probation Officers make a real difference in re-shaping the lives of offenders. ${ }^{27}$

Unlike Singapore, in Malaysia we do not have the provision of voluntary probation officers. However in Malaysia NGOs who are engaged in public welfare activities may be encouraged to take up the job of voluntary probation officers. It is submitted that a comprehensive legislation for probation in Malaysia is needed along similar lines of Singaporean Probation of Offenders Act. The Singaporean experience can be used to a society that shares the same common heritage, legally as well socially, with Malaysia.

\section{FINE}

Fine is preliminary penalty imposed upon a person adjudged guilty of crime. It has been the most commonly used of all the penalties available to the Criminal Courts in Western and Eastern civilizations. ${ }^{28}$

Imposition of fine as a sentence for offences in the Malaysian Penal Code has been dealt with in the following ways:

i) Offences in which fine is the punishment and amount fine is limited. ${ }^{29}$

$26 \quad$ Bee Lian Ang, Community Based Rehabillitation of Offenders in Singapore, Resource Material No. 61 UNAFEI (United Nations Asia and Far East Institute for the Prevention of Crime and Treatment of Offenders) Tokyo, 2002, p. 2.

27 Bee Lian Ang, Voluntary Management in the Probation Service-The case of Singapore, Resource Material No. 61 UNAFEI,Tokyo 2002, p. 174.

28 Caldwell R.G., Criminology, New York, The Renald Press Company (1956), p. 426.

29 Under Sections 137 and 154 of the Penal Code, the fine is the sole punishment and the amount of fine is limited. 
ii) Offences in which it is alternative to punishment but the amount is limited.

iii) Offences in which it is in addition to imprisonment and the amount of fine is unlimited. ${ }^{30}$

Fine as an alternative to short term imprisonment is an important non-custodial penalty available to the Courts in Malaysia but insufficient attention has been paid to it. What useful correctional purpose can it serve? The Law Commissioners of the Indian Penal Code appreciating the efficacy of fine observed:

"We are satisfied that if offenders are allowed to choose between imprisonment and fine, fine will lose its efficacy on those who dread it most. We, therefore, propose that imprisonment which an offender has undergone shall not release him from the preliminary obligation under which he lies”31

It is the main reason that fine has been provided as an important penalty for most of the offences punishable under the Penal Code and other local laws either exclusively or alternatively or in addition to other penalty. ${ }^{32}$ As discussed earlier that a large number of prisoners in the Malaysian prisons consist of short termers, fine can be used in deserving cases be used as a substitute to short term imprisonment At the Hague Conference in 1951, the social, economic and domestic drawbacks of imprisonment were considered. After due deliberation of these drawbacks it was suggested that as far as possible fine should be imposed as substitute for short term imprisonment. ${ }^{33}$

$30 \quad$ Under Sections 155 and 156 of the Penal Code the amount of fine is unlimited. However Section 283(1)(a) of the C.P.C. lays down where no sum is expressed to which a fine is expressed to which a fine may extend to which the offender is liable, shall not be excessive. These provisions vest a discretion the judge to fix any amount if fine depending on the circumstances of the case but it is expected not to impose unreasonable or excessive fine. Chandigarh, Publications Bureau Punjab University (1970), p. 203. Id. Ibid., p. 203. 
Various steps may be taken to improve fine as an effective means of sentence. One suggestion which is very often put forward is that fine should be related more accurately to the offender's ability to pay fine. ${ }^{34}$ The amount of fine imposed should be within the means of the accused to pay though he must be made to feel the pinch of it.

Imposing fine on the offender's ability to pay has merit. A rich person convicted of an offence may be imposed a fine ten times more than on a resource less person. If rich or influential person's are too lightly dealt with though they are guilty, respect for law and order will be seriously impaired. A fine should not be too excessive as to ruin completely the persons on whom it is imposed. The wealth and poverty of an accused are factors, which should be considered on almost every occasion in assessing fines.

In the cases in which it is necessary to impose fine, the Court should take into consideration not only the financial circumstances of the offender, but also the profit arising from the offence, and the value of the subject matter as well as the amount of injury caused by the act of the accused. In Zakaria bin Musa v. Public Prosecutor, ${ }^{35}$ the appellant was charged for theft of a motor car in the Magistrate's Court. He pleaded guilty to the charge and was sentenced to two and half years imprisonment and a fine of $\$ 3000$. On appeal, it was contended by the counsel for the appellant that the sentence was manifestly excessive, as the maximum sentence for theft was three years. It was further submitted that the appellant was a security guard and has been dismissed from his job and was unable to fine. The learned judge agreed with the submission of the counsel and held that if it was really necessary to impose a fine in addition to the custodial sentence, then the trial Magistrate should have taken into consideration, the financial circumstances of the appellant, the profit arising from the offence, the value of the subject matter and the amount of injury, if inflicted.

\footnotetext{
$34 \quad$ Ian Maclean and Peter Monish, Harris's Criminal Law, London, Sweets and Maxwell (1973), p. 776.

35 [1985] 2 MLJ 221.
} 


\section{ATTENDANCE CENTRES}

An Attendance Centre is a community based penal measure, which is used as an alternative to short term imprisonment Attendance Centres are post-war innovations intended to justify the law by imposing a loss of leisure time on the offender as a punishment. The offender spends a period under discipline and is guided to make constructive use of his/her leisure time. It is a place at which youthful offenders are required to be present at a specified place for a certain number of hours and under supervision given appropriate occupations or instructions. The philosophy of an Attendance Centre has its basis from the researches of criminologists who found a correlation between leisure time available to a child and delinquent behaviour. ${ }^{36}$

In Malaysia two such centres were established under Compulsory Attendance Ordinance 1954 in Kuala Lumpur and Penang. The first offenders of minor offences under sentences of three months imprisonment were committed to the centres for not more three hours daily after their usual working hours. They were required to report daily five days a week from 5 p.m. to 8 p.m. The Centres worked for few years, but they soon disappeared as the courts in Kuala Lumpur and Penang rarely applied the Compulsory Attendance Ordinance 1954.

\section{SUGGESTIONS}

In order to achieve the desired effects of non-custodial measures as treatment of offenders, the following suggestions are offered:

The Courts in Malaysia are empowered to release offenders on absolute or conditional discharge. It is submitted that in deserving cases, these benevolent provision should be used more liberally. The use of these provisions may protect many first offenders from the ill effects of prison life.

The experience of the countries where probation system has been effectively used show that it has helped many offenders to change

36 Ahmad Siddique, Criminology, Delhi, Eastern Book Company (2005), p. 146. 
themselves and rehabilitate in the society as a good citizen. ${ }^{37} \mathrm{~A}$ few suggestions are offered to make probation system effectively.

The Malaysian Criminal Procedure Code may suitably be amended to grant probation to adult offenders. This will reduce the pressure on prison and save the short termers from the ill effects of prison life.

In order to reduce the risk to the society attendant upon the inadvertent release on probation of undeserving offenders, the Courts should insist upon receiving full information in the nature of pre-sentence report. This can be done with the help of Social Welfare Department. The probation officers working under the Department may be of assistance to the Courts to furnish such sentence reports. It is submitted that provisions should be made in law making pre-sentence enquiries essential in Malaysia.

Fine can also play a significant role as a non-custodial method of treatment of offender. The Courts should make wider use of it as a penalty. It should be assessed according to the means of offender. In cases of default payment fine or inability to pay, the offender should not be sent to prison instead he might be permitted to pay by installment. It should be made obligatory on the Courts to give sufficient time to the offender to pay fine.

Attendance Centres can also play an important role in treatment of offenders. The great advantage of this penalty is that it serves as a bridge between custodial and non-custodial treatment and satisfies the modern concept of punishment and training offenders without disturbing their family life. It is submitted that since Compulsory Attendance Ordinance 1954 has not been repealed, the attendance centres may be established under the Ordinance to use these as a non-custodial method of treatment of offenders.

$37 \quad$ "The Record of the United Kingdom, Home Office revealed that 90\% adult probationer completed their probation period satisfactorily,” V. Kumar, "Probation of Offenders" [1963] MLJ Ixxiv. A research conducted by the author on probation system in Malaysia showed that in the year 2002, 24 adults (youthful offenders) were placed on probation. All of them completed their probation period successfully. See Mohammad Akram, "Probation of Offenders: A Plea,” [1996] 4 CLJ cxi. 


\section{CONCLUSION}

In order to achieve the desired effects of the implementation of the measures of non-custodial treatment of offenders it is submitted that some of the important problems and constraints which have been addressed in this paper such as the deficiency or requirement of appropriate legislation, the negative attitude of the community, lack of financial resources and inadequacy of research on the rehabilitative effects of non-custodial measures be considered by the respective agencies.

It is believed that if these measures are sincerely taken into view, they can go a long way in reducing the pressure on the prison population as well as providing a holistic approach to save scores of offenders from the contaminated effects of prison life. 